\title{
Seasonality of Batrachochytrium dendrobatidis infection in direct-developing frogs suggests a mechanism for persistence
}

\author{
Ana V. Longo*, Patricia A. Burrowes, Rafael L. Joglar \\ Department of Biology, University of Puerto Rico, PO Box 23360, San Juan, Puerto Rico 00931-3360
}

\begin{abstract}
Batrachochytrium dendrobatidis $(B d)$, a disease-causing amphibian-specific fungus, is widely distributed in Puerto Rico, but is restricted to elevations above $600 \mathrm{~m}$. The effect of this pathogen in the wild was studied by monitoring Eleutherodactylus coqui and E. portoricensis in 2 upland forests at El Yunque, a site characterized by historic population declines in the presence of chytridiomycosis. We tested a potential synergistic interaction between climate and $B d$ by measuring prevalence of infection and level of infection per individual sampled (number of zoospores), across the dry and wet seasons for $2 \mathrm{yr}$ (between 2005 and 2007). Infection levels in adult frogs were significantly higher during the dry season in both species studied, suggesting a cyclic pattern of dry/ cool-wet/warm climate-driven synergistic interaction. These results are consistent with ex situ experiments in which $E$. coqui infected with $B d$ were more susceptible to chytridiomycosis when subjected to limited water treatments resembling drought. Long-term data on the prevalence of $B d$ in the populations studied versus intensity of infection in individual frogs provided contradictory information. However, the conflicting nature of these data was essential to understand the status of $B d$ in the species and geographical area studied. We conclude that in Puerto Rico, $B d$ is enzootic, and vulnerability of eleutherodactylid frogs to this pathogen is related to seasonal climatic variables. Our data suggest a mechanism by which this disease can persist in tropical frog communities without decimation of its hosts, but that complex interactions during severe droughts may lead to population crashes.
\end{abstract}

KEY WORDS: Batrachochytrium dendrobatidis - Amphibian declines · Climate-disease synergy · Seasonal patterns $\cdot$ Eleutherodactylus

Resale or republication not permitted without written consent of the publisher

\section{INTRODUCTION}

Puerto Rico has lost 3 species of endemic anurans in the last 3 decades: Eleutherodactylus karlschmidti (1976), E. jasperi (1981), and E. eneidae (1990) (Joglar \& Burrowes 1996, Burrowes et al. 2004). In addition, long-term amphibian monitoring data revealed that 8 populations of 6 different species declined at El Yunque, a mountain forest reserve in eastern Puerto Rico, between 1990 and 2000 (Burrowes et al. 2004). Declines in populations of $E$. coqui have been linked to increments in the number of dry periods, defined as 5 or more consecutive days with $\leq 3 \mathrm{~mm}$ of precipitation (Stewart 1995). Burrowes et al. (2004) reported an increase of $1^{\circ} \mathrm{C}$ in the minimum temperature at $\mathrm{El}$ Yunque from 1970 to 2000, and found that the number of dry periods during the dry season increased significantly in the mid-1970s and early 1990s. These climatic changes are correlated with the years of anuran disappearances in Puerto Rico, and the first occurrence of Batrachochytrium dendrobatidis $(B d)$ in several declining species at El Yunque (Burrowes et al. 2004, 2008).

$B d$ infections have been associated with mass mortality and declines of amphibians around the world (Berger et al. 1998, Lips et al. 2006, Skerratt et al. 2007). Laboratory studies have shown that amphibian susceptibility to $B d$ infection varies across taxonomic, ontogenetic, and thermal conditions (Lamirande \& 
Nichols 2002, Davidson et al. 2003, Berger et al. 2004, Daszak et al. 2004), but little is known about the interactions of this pathogen and its hosts in the wild. Retallick et al. (2004) showed a seasonal peak of infections during the cooler months of the year in 1 geographic region in Australia, and Kriger \& Hero (2006) found that frogs that were infected during the winter could clear the infection during the warmer months. However, studies of this type in the Neotropics, and particularly among direct-developing frogs that appear to be more resistant to $B d$ (Lips et al. 2003, Bustamante et al. 2005), have not been conducted. Amphibian communities devastated by $B d$ in Central America have been left with few resistant species, although several are terrestrial direct developers (Lips et al. 2003, 2006). Thus, it is important to understand the interactions between $B d$ and Eleutherodactylus species, because these may be the only amphibians left at some places after a $B d$ epidemic. $B d$ is present throughout Puerto Rico in 9 species of Eleutherodactylus and 1 Leptodactylus at elevations above $600 \mathrm{~m}$ (Burrowes et al. 2008).

Here we present the results of $2 \mathrm{yr}$ of consecutive monitoring of Eleutherodactylus coqui and E. portoricensis in 2 upland forests in Puerto Rico, characterized by historic population declines in the presence of chytridiomycosis. We tested the hypothesis of a synergistic interaction between climate and $B d$ as suggested by Burrowes et al. (2004), by monitoring prevalence of $B d$ (number of infected frogs per total sampled), and level of infection (number of zoospores) in individuals from populations in the wild. In addition, we conducted an ex situ experiment where we simulated seasonal climatic conditions in the laboratory, inoculated frogs with $B d$, and observed their behavior and susceptibility to infection. Previous experiments showed that E. coqui frogs exposed to drought conditions in the laboratory clumped in humid areas of the terraria, while frogs that had unlimited moisture did not clump (Joglar et al. 2007). Thus, we expected that if host-pathogen dynamics are influenced by climatic conditions, $B d$ infection loads of individuals in the wild would be higher during the dry season when temperatures are lower, and drought-stressed frogs would clump in humid pockets of the forest where the fungus is more likely to occur (Burrowes et al. 2004). In addition, we expected that under laboratory conditions of drought, frogs would be more likely to die from chytridiomycosis. However, if seasonal climatic variables do not affect vulnerability and/or pathogenicity of $B d$, we expected to find no differences in infection load, prevalence, or experimental survivorship of inoculated frogs between seasons or treatments. Results of this work are important in order to understand the dynamics of $B d$ when it is endemic in populations of presumably less vulnerable terrestrial direct-developing frogs.

\section{MATERIALS AND METHODS}

Study sites. This study took place at El Yunque Caribbean National Forest in eastern Puerto Rico at 2 different elevations, Palo Colorado Forest $\left(18.30^{\circ} \mathrm{N}\right.$, $\left.65.79^{\circ} \mathrm{W}\right)$ at $661 \mathrm{~m}$, and Bosque Enano Forest $\left(18.30^{\circ} \mathrm{N}, 65.79^{\circ} \mathrm{W}\right)$ at $850 \mathrm{~m}$. Palo Colorado Forest is part of the subtropical wet forest association (Ewel \& Whitmore 1973), and is characterized by abundant Cyrilla racemiflora. Bosque Enano Forest is an elfin forest near Mt. Britton classified as lower montane wet forest by Holdridge Life Zones (Ewel \& Whitmore 1973) and is characterized by the abundance of Ocotea spathulata and Eugenia borinquensis.

Field work. Amphibian populations were monitored for $B d$ infection every month for $2 \mathrm{yr}$ (starting in September 2005). Visual encounter surveys were conducted in $300 \mathrm{~m}^{2}$ (100 $\mathrm{m}$ long $\times 3 \mathrm{~m}$ wide) transects at the 2 study sites. Frogs were captured in individual plastic bags worn as gloves and inverted to prevent cross contamination. A fresh pair of powder-free nitrile gloves was worn every time a different frog was manipulated. Individuals were sampled for $B d$ by swabbing their ventrum, feet, and toes as described by Kriger et al. (2006). Swabs were stored at $-20^{\circ} \mathrm{C}$ upon arrival at the laboratory. Each frog was toe clipped following a modification of Twitty's (1966) code for an ongoing mark-recapture study, and toes were used for $B d$ diagnostics. This code allowed us to take tissue from different limbs of the frog minimizing the impact of toe-clipping (P. Burrowes \& A. Longo unpubl. data). Toe clips were stored in $70 \%$ ethanol and kept at room temperature until DNA was extracted for $B d$ diagnosis.

Batrachochytrium dendrobatidis diagnosis. In this study, only frog toe clips were used as tissue for disease diagnosis. Toe clippings were preferred over swabs, because when comparing results from swabs and toes from the same frog, we found that swabs did not detect low-level infection (A. Longo \& P. Burrowes unpubl. data). $B d$ pathogen load was diagnosed following the Taqman quantitative-PCR (qPCR) method to determine the number of $B d$ zoospores per individual. Samples were run on singlicates, but repeated if the quantity was $<1$ zoospore equivalent (Boyle et al. 2004). To correct for potential underestimation of $B d$ zoospores in toe clips, and to make our data more comparable to that reported from swabs of similar size frogs, the number of zoospore equivalents obtained from qPCR detection was multiplied by the snout-vent length (SVL) of each individual. This number is also an indication of intensity of infection, and we refer to it as the $B d$ load. The mean \pm SE SVL for Eleutherodactylus coqui was $34.9 \pm 0.39 \mathrm{~mm}$ in males and $43.7 \pm 0.39 \mathrm{~mm}$ in females; for $E$. portoricensis, it was $32.2 \pm 0.36 \mathrm{~mm}$ in males and $37.8 \pm 0.43 \mathrm{~mm}$ in females. 
Bd inoculation ex situ experiment. Adult Eleutherodactylus coqui were collected from El Yunque at Palo Colorado forest, very close but not in our transects. Every individual was tested for $B d$, and only $B d$-negative frogs were used in the experiments. Infected frogs were treated with Itraconazole ${ }^{\circledR}$ (Nichols \& Laraminde 2001), held in a separate room, and released in the wild when they had cleared the infection. Healthy frogs were acclimated in 1101 terraria for $2 \mathrm{wk}$ before experiments began. Terraria were prepared with potting soil and contained 4 potential retreat sites consisting of parts of rolled yagrumo Cecropia peltata leaves, bamboo shoots, palm fronds, and 2 large branches (Fig. 1). Four adult E. coqui frogs of the same sex were held in each terrarium with equal numbers of refugia and sufficient food, and kept at a 12:12 h night:day cycle at $20.5^{\circ} \mathrm{C}$ to simulate nocturnal temperatures at El Yunque during the dry season. By the time the experiments were started, all frogs were in healthy condition, $B d$-free, eating well, and distinguishable through unique toe-clip codes. The experiment consisted of 12 terraria (110 l) comprising 3 replicates each of 4 different treatments where frogs were (1) inoculated with $B d$ under drought conditions (experimental positives);
(2) not exposed to $B d$, but under drought conditions (experimental negatives); (3) inoculated with $B d$ under humid conditions (control positives); and (4) not exposed to $B d$ or drought (control negatives). To simulate drought conditions in the experimental terraria, the substrate was divided in 2 halves with aluminum trays that prevented diffusion of water from the side that was kept humid to the side that was kept dry (Fig. 1A). During the acclimation period and throughout the experiments, experimental terraria were hydrated every $4 \mathrm{~d}$ by applying water directly (not sprayed) to the wet side only, while the controls received water throughout the entire substrate every other day. The purpose of this water treatment in the experimental terraria was to simulate the understory forest conditions during drought, when frogs tend to clump in humid areas and share retreat sites (Joglar et al. 2007).

$B d$ isolate JEL427 was obtained from a sick Eleutherodactylus coqui collected at our study site in El Yunque, and sent to J. Longcore at the University of Maine (USA) for initial isolation and culture. Zoospores were harvested by flooding $B d$-rich plates with distilled water for $15 \mathrm{~min}$ and using a pipette to collect them. The specific zoospore concentration for inocula-
A Experimental positive

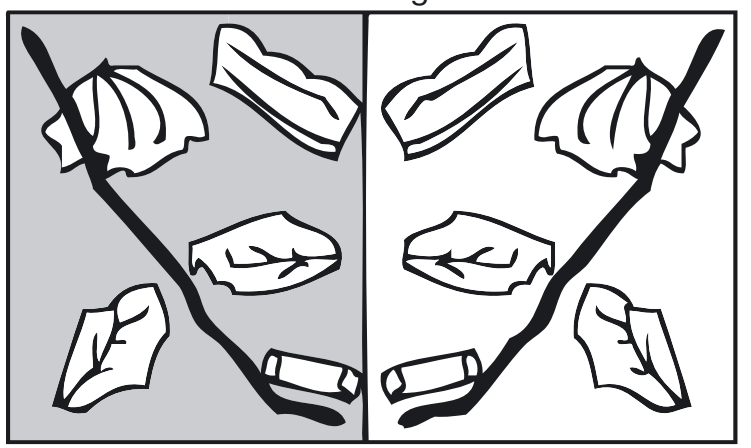

B

Control positive $B d+$ unlimited water

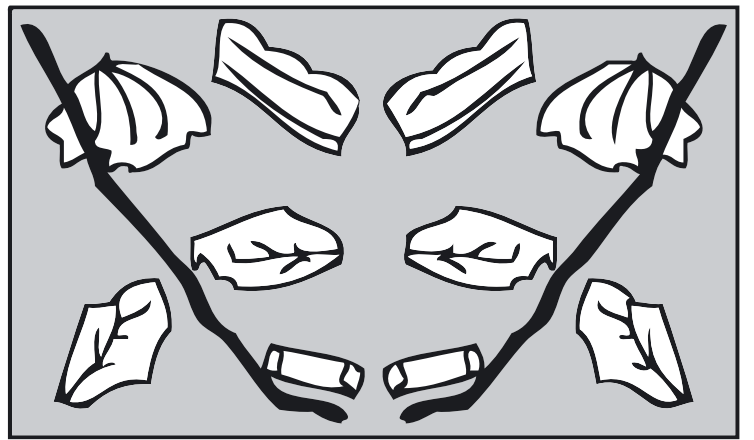

Experimental negative No $B d+$ drought

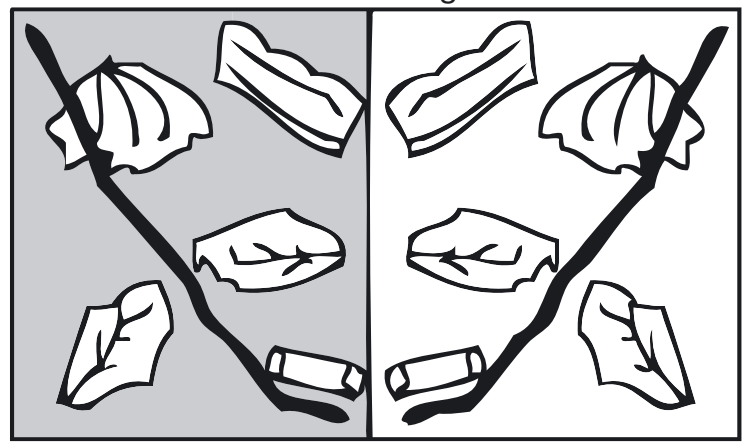

Control negative

No $B d+$ unlimited water

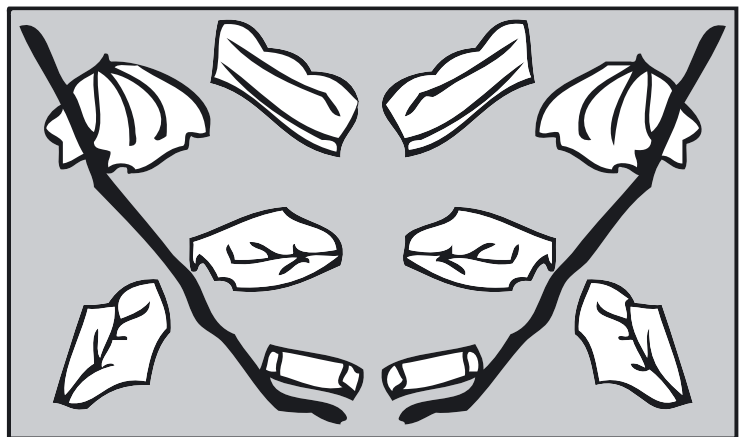

Fig. 1. Setup of the terraria used in $B d$ inoculation ex situ experiments: (A) experimental terraria in which only half of the substrate was watered every $4 \mathrm{~d}$, simulating drought conditions, and (B) control terraria in which water was applied throughout the substrate every other day. Experimental conditions led to frogs clumping in the humid side of the terraria. Each terrarium was prepared with potting soil and contained rolled leaves, bamboo shoots, palm fronds, and 2 large branches 
tions was estimated by counting the zoospores under a light microscope at $400 \times$ with a hemocytometer, then diluted to $10^{5} \mathrm{Bd}$ zoospores $\mathrm{ml}^{-1}$. Frogs in experimental positive and control positive treatments were inoculated with $B d$ for 4 consecutive days. On inoculation days, frogs were removed from their terraria and housed individually in a plastic container with $10 \mathrm{ml}$ of the $B d$ zoospore solution during $10 \mathrm{~h}$ of daytime (from 8:00 to $18: 00 \mathrm{~h}$ ), and then returned to their respective terrarium. Plastic containers were covered with large perforated carton boxes to simulate relatively dark diurnal retreat sites. Experimental negative and control negative frogs were treated in the same manner, except that the water in the containers was not inoculated with $B d$ zoospores. Frog behavior, sickness symptoms, use of retreat sites, and death were monitored daily for $15 \mathrm{~d}$. When frogs were found dead, tissue samples were taken to confirm infection status via qPCR. Koch's postulates were fulfilled to confirm cause of death by chytridiomycosis in 6 of 12 dead frogs. All surviving frogs that had been inoculated with $B d$ were euthanized after the experiment. This experiment was done twice to confirm repeatability.

Data analysis. To test for differences in $B d$ infection level of individuals (measured in zoospores and $B d$ load) between seasons in Puerto Rico, we used a Mann-Whitney $(W)$ test. Prevalence (number of infected frogs/total sampled) of $B d$ in frog populations between seasons was compared using a $t$-test. To assess the status of $B d$ in frog populations over time, we compared prevalence and level of infection between years (2005-2006; 20062007) using 2-proportion $(Z)$ and Mann-Whitney tests, respectively. A Logrank test on censored survival data was performed to examine differences in frog survival per treatment in ex situ experiments. All statistical tests were done with Minitab Release 15. Weather data on daily precipitation and minimum temperature were taken from the Long Term Ecological Research Station (LTER) of El Verde, Puerto Rico, located $4.2 \mathrm{~km}$ NW of our study sites.

\section{RESULTS}

\section{Infection level and prevalence in wild populations}

Analysis of climatic variables with respect to daily precipitation and minimum temperature, which are important variables both in amphibian and Bd biology (Carey \& Alexander 2003, Piotrowski et al. 2004, Pounds et al.
2006), were analyzed for the 2 yr of monitoring starting in September 2005 through September 2007. Longterm analysis of climatic variables have shown that the climate of Puerto Rico is characterized by 2 seasons: one with higher precipitation and warmer temperatures, and another that is drier and cooler (Colón 1983, Burrowes et al. 2004). Fig. 2 shows that despite a few anomalies, the years of this study reflect this seasonality. We will refer to these seasons as wet-warm and dry-cool, respectively.

The level of $B d$ infection in positively diagnosed frogs from wild populations was significantly different across seasons, independent of the type of measure used (Table 1). In Eleutherodactylus coqui, both the mean number of zoospores (from toe clips) and the mean $B d$ load (zoospores $\times$ SVL) were significantly higher in the dry-cool season $(W=14095, \mathrm{~N}=212, \mathrm{p}=$ $0.0004 ; W=14087, \mathrm{~N}=212, \mathrm{p}=0.0004$, respectively). The same pattern was observed for E. portoricensis a few meters higher in El Yunque forest, where the mean number of zoospores $(W=3991.5, \mathrm{~N}=125, \mathrm{p}=$ 0.0165 ) and the mean $B d$ load ( $W=4040, \mathrm{~N}=125, \mathrm{p}=$ 0.0311 ) were higher during the dry-cool months. However, monthly prevalence of $B d$ in the populations showed the opposite pattern. From a total of 321 individuals of E. coqui sampled in the Palo Colorado forest, 212 were positively diagnosed with $B d$. More frogs were found infected during the wet-warm season (Table 1), where prevalence was approximately $25 \%$ higher than in dry-cool months $(Z=4.80, N=321,95 \%$ $\mathrm{CI}=0.15-0.36, \mathrm{p}<0.000)$. This trend was also significant for E. portoricensis $(Z=3.07, \mathrm{~N}=204,95 \% \mathrm{CI}=$ $0.07-0.34, \mathrm{p}=0.004$ ) for which the prevalence during the wet-warm season was $30 \%$ greater than in the dry-
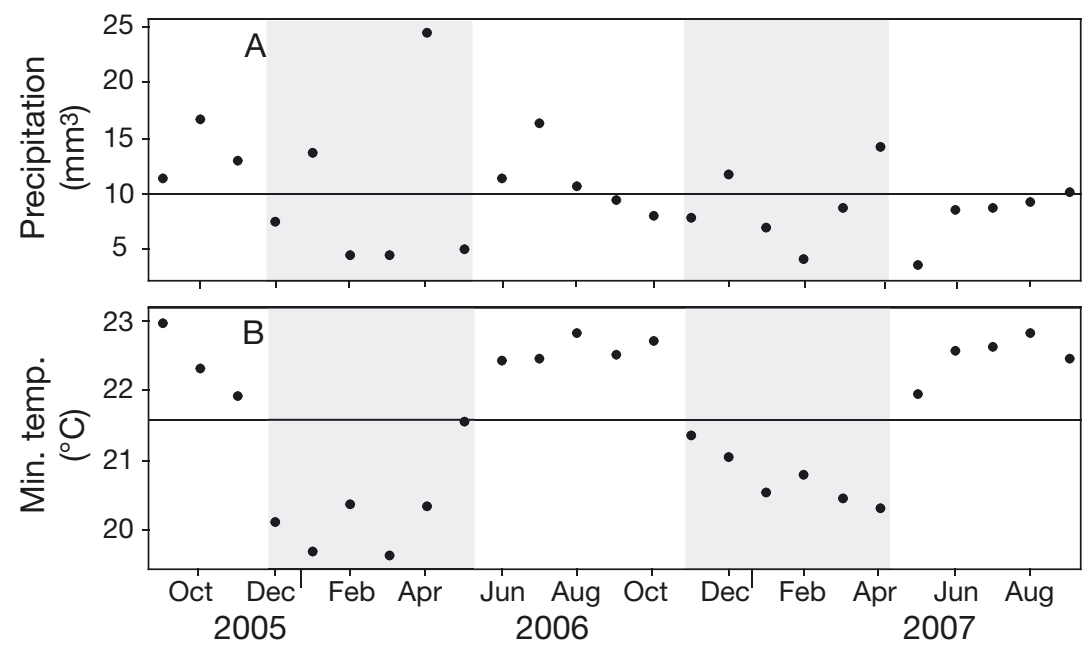

Fig. 2. Variation in (A) mean precipitation and (B) mean minimum temperature during our 2 yr study period. The gray area denotes the dry-cool season, and the white area corresponds to the wet-warm season. The solid line across each graph corresponds to the mean for the 24 mo considered: (A) $9.9 \mathrm{~mm}^{3}$ and (B) $21.5^{\circ} \mathrm{C}$ 
Table 1. Seasonal differences in Batrachochytrium dendrobatidis $(B d)$ infection level and prevalence in 2 populations of Eleutherodactylus at Palo Colorado (PC) and Bosque Enano (BE) forests in El Yunque, Puerto Rico. Infection level is reported as the mean $( \pm \mathrm{SD})$ number of zoospores detected in positive individuals, and as mean $( \pm \mathrm{SD}) B d$ load (zoospores $\times$ snout-vent length of positive individuals). Asterisks indicate the level of significant difference between seasons: ${ }^{*} p<0.05,{ }^{* *} p<0.01,{ }^{* * *} p<0.001$

\begin{tabular}{|c|c|c|c|c|c|c|}
\hline Species & Forest & Season & $\begin{array}{l}\text { Zoospores } \\
\text { (range) }\end{array}$ & $\begin{array}{l}B d \text { load } \\
\text { (range) }\end{array}$ & $\begin{array}{c}\text { Prevalence }(\%), \\
\text { (Ninfected/total sampled) }\end{array}$ & $\begin{array}{c}95 \% \mathrm{CI} \\
\text { of prevalence }\end{array}$ \\
\hline \multirow[t]{2}{*}{ E. coqui } & \multirow[t]{2}{*}{$\mathrm{PC}$} & Wet-warm & $\begin{array}{l}24 \pm 61 \\
(1-629)\end{array}$ & $\begin{array}{l}873 \pm 2242 \\
(37-23002)\end{array}$ & $\begin{array}{c}76.4 \\
(146 / 191)^{* * *}\end{array}$ & $69.8-82.3$ \\
\hline & & Dry-cool & $\begin{array}{c}290 \pm 1317 \\
(1-9450)^{* * *}\end{array}$ & $\begin{array}{c}12838 \pm 67073 \\
(58-527972)^{* * *}\end{array}$ & $\begin{array}{c}50.8 \\
(66 / 130)\end{array}$ & $41.9-59.6$ \\
\hline \multirow[t]{2}{*}{ E. portoricensis } & \multirow[t]{2}{*}{$\mathrm{BE}$} & Wet-warm & $\begin{array}{c}148 \pm 622 \\
(1.1-3335)\end{array}$ & $\begin{array}{c}4783 \pm 20356 \\
(30-128572)\end{array}$ & $\begin{array}{c}71.4 \\
(70 / 98)^{*}\end{array}$ & $61.4-80.1$ \\
\hline & & Dry-cool & $\begin{array}{c}230 \pm 1544 \\
(1-11253)^{* *}\end{array}$ & $\begin{array}{c}7362 \pm 49084 \\
(44-357839)^{* *}\end{array}$ & $\begin{array}{c}41.0 \\
(54 / 106)\end{array}$ & $41.0-60.8$ \\
\hline
\end{tabular}

cool months. Thus, data on $B d$ prevalence suggest a different response to seasonality than data on the intensity of infection. While prevalence is a population-level measure of infection status, zoospore counts provide information on individual susceptibility to chytridiomycosis. A comparison of the status of $B d$ in populations over time showed that while infection level in adults of both species decreased significantly from the first year of this study (2005-2006) to the next (2006-2007), prevalence in the populations increased. Thus, more frogs had $B d$ but at lower levels of infection (Table 2).

\section{Ex situ inoculation experiments}

Results of our laboratory experiment showed that after 4 consecutive days of $B d$ inoculations at $10^{6}$ zoospores per individual, only frogs subjected to $B d$ and drought died (Fig. 3). Only frogs in the drought treatments clumped under refugia in the humid side of the terraria, as reported by Joglar et al. (2007). Frog health changed drastically after inoculations with $B d$. These frogs started showing signs of chytridiomycosis such as skin sloughing, lethargy, inability to respond to stimulus, and necrosis around the snout and abdomen after the second day of inoculation (Fig. 4). Although frogs in the control positive terraria contracted $B d$ (detected by qPCR), symptoms of chytridiomycosis were not as severe, and they persisted throughout the experiment. From Days 3 to 11 after Bd exposure, 50\% (12) of the frogs died of chytridiomycosis in the experimental positive treatment. At the time of death, all frogs had $B d$ present on their skin, confirmed by qPCR analyses. Frogs did not die in any of the other treatments; neither $B d$ alone (control positive) nor drought

Table 2. Status of Batrachochytrium dendrobatidis ( $B d$ ) over time in 2 populations of Eleutherodactylus at Palo Colorado (PC) and Bosque Enano (BE) forests in El Yunque, Puerto Rico. Infection level is reported as the mean $( \pm \mathrm{SD})$ number of zoospores detected in positive individuals, and as mean $( \pm \mathrm{SD}) \mathrm{Bd}$ load (zoospores $\times$ snout-vent length of positive individuals)

\begin{tabular}{|c|c|c|c|c|c|c|}
\hline Species & Forest & Year & $\begin{array}{l}\text { Zoospores } \\
\text { (range) }\end{array}$ & $\begin{array}{l}B d \text { load } \\
\text { (range) }\end{array}$ & $\begin{array}{c}\text { Prevalence }(\%) \\
\text { (Ninfected/total sampled) }\end{array}$ & $\begin{array}{c}95 \% \mathrm{CI} \\
\text { of prevalence }\end{array}$ \\
\hline \multirow[t]{2}{*}{ E. coqui } & \multirow[t]{2}{*}{$\mathrm{PC}$} & 2005-2006 & $\begin{array}{c}258 \pm 1292 \\
(6-9450)\end{array}$ & $\begin{array}{c}13116 \pm 70705 \\
(277-527972)\end{array}$ & $\begin{array}{c}38.5 \\
(55 / 143)\end{array}$ & $30.5-47$ \\
\hline & & $2006-2007$ & $\begin{array}{c}48 \pm 398 \\
(1-4926) \\
W=8963.0 \\
\mathrm{~N}=212, \mathrm{p}<0.000\end{array}$ & $\begin{array}{c}1418 \pm 10286 \\
(37-12095) \\
W=8926.5 \\
\mathrm{p}<0.000\end{array}$ & 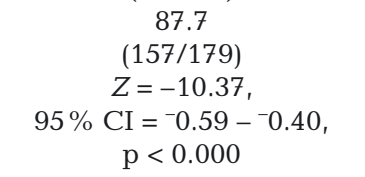 & $82-92.1$ \\
\hline \multirow[t]{2}{*}{ E. portoricensis } & \multirow[t]{2}{*}{$\mathrm{BE}$} & 2005-2006 & $\begin{array}{c}180 \pm 715 \\
(1-3335)\end{array}$ & $\begin{array}{c}5765 \pm 23388 \\
(40-128572)\end{array}$ & $\begin{array}{c}41.6 \\
(42 / 101)\end{array}$ & $31.9-51.8$ \\
\hline & & $2006-2007$ & $\begin{array}{c}158 \pm 1236 \\
(1-11253) \\
W=3264.0 \\
\mathrm{~N}=125, \mathrm{p}<0.001\end{array}$ & $\begin{array}{c}5072 \pm 39309 \\
(30-357839) \\
W=3229.5 \\
\mathrm{p}=0.002\end{array}$ & $\begin{aligned} & 80.6 \\
&(83 / 103) \\
& Z=-6.23 \\
& 95 \% \mathrm{CI}=-0.51-{ }^{-0.27} \\
& \mathrm{p}<<0.000\end{aligned}$ & $71.6-87.7$ \\
\hline
\end{tabular}




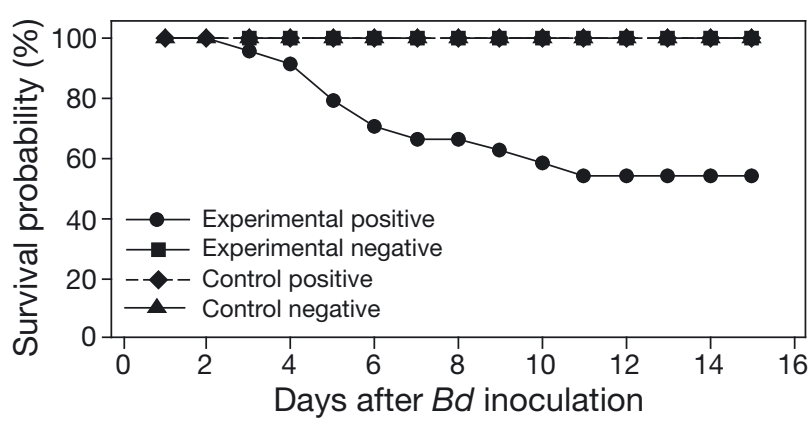

Fig. 3. Eleutherodactylus coqui. Survival probability in ex situ experiments under 4 different treatments. Only frogs subjected to Batrachochytrium dendrobatidis $(B d)$ and drought in one-half of the terraria (experimental positive treatment) died from chytridiomycosis

alone (experimental negative) resulted in deaths. These results show that Eleutherodactylus coqui adults are significantly more likely to die from chytridiomycosis when subjected to limited water treatments that induce clumping at humid retreat sites (Logrank test, $\mathrm{p}<0.000, \mathrm{~N}=24$ per treatment), and support the hypothesis that vulnerability to chytridiomycosis is associated with seasonality.

\section{DISCUSSION}

Our ex situ experiments provide evidence that drought conditions under cool temperatures increased vulnerability of frogs to chytridiomycosis. In the laboratory, $50 \%$ of the frogs exposed to $B d$ and drought

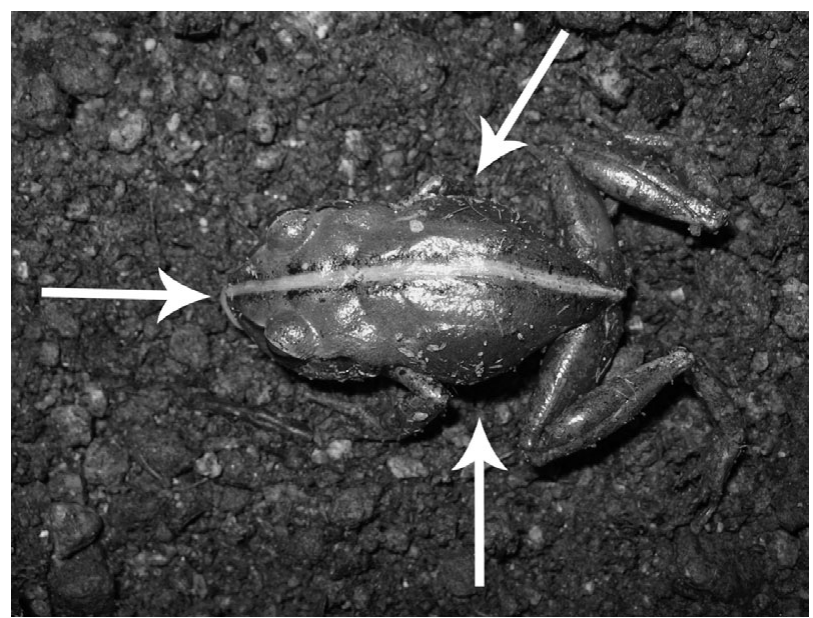

Fig. 4. Eleutherodactylus coqui. Photograph showing necrosis of the skin on the snout and dorso-lateral areas (arrows), presumably caused by $B d$ infection. This frog died from chytridiomycosis on Day 6 after inoculation with Batrachochytrium dendrobatidis $(B d)$ under the experimental positive treatment. Photograph taken by C. Rodríguez died (experimental positives), while all those exposed to other treatments, including $B d$ and unlimited water, survived (Fig. 3). The fact that clumping in refugia on humid sides of the terraria occurred only under drought treatments suggests that a drought-induced behavioral change (i.e. clumping) increases susceptibility of these terrestrial frogs to $B d$.

Patterns of $B d$ infection in wild populations are much more difficult to discern, especially in this genus of frogs, since they do not congregate in ponds or streams to reproduce. If an Eleutherodactylus is sick from chytridiomycosis, it is likely to stay in its retreat site where herpetologists cannot find it. This $2 \mathrm{yr}$ study allowed us to monitor enough frogs in the field to show that infection levels of $B d$ were significantly higher during the dry-cool season (Table 1). Thus, we provide ex situ and in situ evidence in favor of the climatelinked epidemic hypothesis as originally described by Pounds \& Crump (1994) and proposed for Puerto Rican frogs by Burrowes et al. (2004). This hypothesis proposes that under the environmental stress that drought brings about to amphibians (Carey et al. 2003) E. coqui change their random distribution in the forest and clump in humid patches where the chytrid fungus is more likely to occur. Drought and clumping at retreat sites enhance the vulnerability of frogs to $B d$ infection at a time when environmental temperatures (mean minimum temperature $=20.52^{\circ} \mathrm{C}$, Fig. 2) favor its growth (Piotrowski et al. 2004). Thus, under extreme drought conditions such as those described for the years of drastic declines in Puerto Rico (1976 to 1978 and 1981; Burrowes et al. 2004), an epidemic may drive the extirpation of populations even when $B d$ is enzootic in a geographical area.

The fact that the prevalence of infection is higher during the wet-warm months leads us to propose a cyclic synergistic effect between seasonality and infection that explains $B d$ persistence in populations of these 2 resistant, yet vulnerable, species of Eleutherodactylus (Fig. 5). During the dry-cool season, fewer frogs are active in the forest because they spend more time in retreat sites to reduce water loss (Pough et al. 1983, Joglar 1998). Thus, the frogs that are sampled during these times are those that have overcome lower temperatures and drier conditions successfully. Frogs that were positive for $B d$ during the dry-cool season had significantly higher infection levels than those in the wet season, but prevalence of $B d$ was lower because very sick frogs remain inactive in their retreat sites, and the probability of capturing an infected frog decreases. During the wet season, as temperature increases, survivors recuperate and persist but still carry a low $B d$ load. Prevalence of $B d$ in the population is higher because frogs are not that sick, and the probability of sampling an infected individual increases. With lower infection levels in the wet- 
warm season, frogs are able to reproduce, and therefore the population recuperates. This cycle (Fig. 5) describes a possible mechanism that allows $B d$ to thrive without decimation of its hosts. This synergistic interaction between $B d$ and seasonal temperature and precipitation may explain why species in this ecological guild (terrestrial direct-developers) are less vulnerable to $B d$ in tropical forest communities as found by Lips et al. (2003) and Bustamante et al. (2005) in Central and South America.

The disparity observed between measures of $B d$ load in individuals versus prevalence of $B d$ in populations at a given time indicates that differences between prevalence and level of infection parameters are important. Prevalence describes the status of infection in a population at a given time, while level of infection (number of zoospores or $B d$ load) provides information on the response of a subgroup of individuals (the infected) to this pathogen. When $B d$ is enzootic, and environmental conditions are not stressful to the amphibians or favor $B d$ physiology, prevalence may be high while $B d$ load in infected individuals is low, allowing frogs to persist. On the other hand, when environmental conditions become stressful, as during droughts in Puerto Rico, prevalence does not change significantly, but infected individuals have a higher $B d$ load. Therefore, low prevalence of $B d$ does not necessarily imply low risk of infection or low susceptibility to this pathogen in terrestrial frogs as has been suggested by Kriger \& Hero (2007).

In this paper we show that declining populations of 2 species of Eleutherodactylus in Puerto Rico respond to

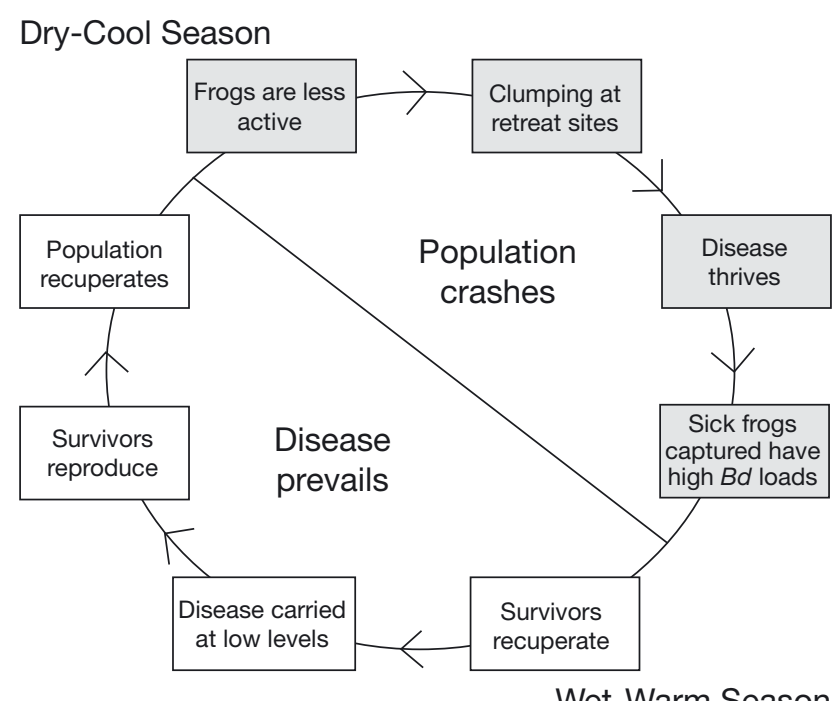

Fig. 5. Diagrammatic representation of the proposed cyclic synergistic interaction between seasonality in Puerto Rico and the behavioral and population response of direct-developing frogs to Batrachochytrium dendrobatidis $(B d)$ infection
$B d$ in a similar way with respect to climatic variables that determine seasonality. The fact that $B d$ infection levels of adult individuals decreased significantly between the $2 \mathrm{yr}$ of this study, while prevalence increased in the populations (Table 2), suggests that $E$. coqui and E. portoricensis are persisting with a stable infection typical of enzootic conditions (Retallick et al. 2004, Briggs et al. 2005). Although E. coqui and E. portoricensis may be able to survive through the cyclic seasonal mechanism proposed (Fig. 5), they can serve as carriers of $B d$ to other species that are rare, have higher degrees of local endemism, are more ecologically specialized, and may be more vulnerable to this pathogen. Thus, even under enzootic conditions, $B d$ can still be a threat to anuran biodiversity. Three species are extinct in Puerto Rico possibly due to chytridiomycosis (Burrowes et al. 2004, 2008), and there are other at-risk species, such as E. locustus, E. richmondi, and E. wightmanae, whose survival may be further compromised by E. coqui and E. portoricensis that act as reservoirs of $B d$.

At a time when more data are needed to explain the link between climate change and amphibian declines (Rohr et al. 2008), our work provides evidence of increased vulnerability of direct-developing frogs to $B d$ under drought conditions. Climate change models predict increased episodes of drought in the Caribbean for the next 50 yr (Christensen et al. 2007). Under this scenario, persisting populations of Eleutherodactylus in Puerto Rico could be at major risk. This study contributes to our understanding of how $B d$ affects persistent populations, but further studies on $B d$ movement patterns, environmental interactions, defense mechanisms, and disease physiology are needed in order to devise conservation measures to curtail global amphibian declines and extinctions.

Acknowledgements. We are thankful to many students in the Joglar/Burrowes Lab, but especially to C. A. Rodríguez and A. López, who provided help with field work at El Yunque. We thank S. Ayala and B. Bolaños at RCM-UPR for kindly sharing their laboratory equipment for $B d$ diagnosis and culture maintenance. Zoospore equivalent standards for $\mathrm{qPCR}$ detection were kindly provided by D. Boyle at CSIRO Australia, and J. Longcore supplied initial $B d$ cultures. Two anonymous reviewers contributed comments that improved earlier versions of this manuscript. Funding for this study was provided by UPR-FIPI, NSF's Alliance for Minority Participation (grant no. HRD-0114586), Proyecto Coquí, and CRESTCATEC (at UPR). We complied with all the Institutional Animal Care and Use Committee (IACUC) guidelines (Animal Welfare Assurance No. A-3258-001; Protocol: 502-2006). Amphibian tissues and animals were collected under Puerto Rican Department of Natural Resources permit numbers DRNA 04-IC-003, 04-IC-062, 05-IC-051-052, and 06-IC-039IC-052. 


\section{LITERATURE CITED}

Berger L, Speare R, Daszak P, Green DE and others (1998) Chytridiomycosis causes amphibian mortality associated with population declines in the rain forests of Australia and Central America. Proc Natl Acad Sci USA 95: 9031-9036

Berger L, Speare R, Hines H, Marantelli G and others (2004) Effect of season and temperature on mortality in amphibians due to chytridiomycosis. Aust Vet J 82:434-439

Boyle DG, Boyle DB, Olsen V, Morgan JAT, Hyatt AD (2004) Rapid quantitative detection of chytridiomycosis (Batrachochytrium dendrobatidis) in amphibian samples using real-time Taqman PCR assay. Dis Aquat Org 60:141-148

Briggs CJ, Vredenburg VT, Knapp RA, Rachowicz LJ (2005) Investigating the population-level effects of chytridiomycosis: an emerging infectious disease of amphibians. Ecology 86:3149-3159

Burrowes PA, Joglar RL, Green DE (2004) Potential causes for amphibian declines in Puerto Rico. Herpetologica 60: 141-154

Burrowes PA, Longo AV, Joglar RL, Cunningham AA (2008) Geographic distribution of Batrachochytrium dendrobatidis in Puerto Rico. Herpetol Rev 39:321-324

Bustamante MR, Ron SR, Coloma LA (2005) Cambios en la diversidad en siete comunidades de anuros en los Andes de Ecuador. Biotropica 37:180-189

Carey C, Alexander MA (2003) Climate change and amphibian declines: Is there a link? Divers Distrib 9:111-121

Carey C, Corn PS, Jones MS, Livo LJ, Muths E, Loeffler CW (2003) Environmental and life history factors that limit recovery. In: Lanoo M (ed) Southern Rocky Mountain populations of boreal toads (Bufo boreas). Status and conservation of North American amphibians. University of California Press, Berkeley, CA, p 222-236

Christensen JH, Hewitson B, Busuioc A, Chen A and others (2007) Regional climate projections. University Press, Cambridge

Colón J (1983) Algunos aspectos de la climatología de Puerto Rico. Acta Cient 1:55-63

Daszak P, Strieby A, Cunningham A, Longcore J, Brown C, Porter D (2004) Experimental evidence that the bullfrog (Rana catesbeiana) is a potential carrier of chytridiomycosis, an emerging fungal disease of amphibians. Herpetol J 14:201-207

Davidson EW, Parris M, Collins JP, Longcore JE, Pessier AP, Brunner J (2003) Pathogenicity and transmission of chytridiomycosis in tiger salamanders (Ambylostoma tigrinum). Copeia 601-607

Ewel JJ, Whitmore JL (1973) The ecological life zones of Puerto Rico and the U.S. Virgin Islands. Forest Service Research Paper ITF-18, USDA, Rio Piedras, PR

Joglar R (1998) Los coquíes de Puerto Rico: su historia natural y conservación. Editorial de la Universidad de Puerto Rico, San Juan

Joglar R, Burrowes P (1996) Declining amphibian populations in Puerto Rico. In: Powell R, Henderson RW (eds) Contributions to West Indian herpetology: a tribute to Albert

Editorial responsibility: Alex Hyatt, Geelong, Victoria, Australia
Schwartz, Vol 12. Society for the Study of Amphibians and Reptiles, Contributions to Herpetology, Ithaca, NY, p 371-380

Joglar RL, Álvarez AO, Aide TM, Barber D and others (2007) Conserving the Puerto Rican herpetofauna. Appl Herpetol $4: 327-345$

Kriger KM, Hero J (2006) Survivorship in wild frogs infected with chytridiomycosis. EcoHealth 3:171-177

> Kriger KM, Hero JM (2007) The chytrid fungus Batrachochytrium dendrobatidis is non-randomly distributed across amphibian breeding habitats. Divers Distrib 13:781-788

Kriger KM, Hines HB, Hyatt AD, Boyle DG, Hero JM (2006) Techniques for detecting chytridiomycosis in wild frogs: comparing histology with real-time Taqman PCR. Dis Aquat Org 71:141-148

Lamirande EW, Nichols DK (2002) Effects of host age on susceptibility to cutaneous chytridiomycosis in blue-andyellow poison dart frogs (Dendrobates tinctorius). In: McKinnell RG, Carlson DL (eds) Proc 6th Int Symp Pathol Reptiles Amphibians, Saint Paul, MN, p 3-13

Lips KR, Reeve JD, Witters LR (2003) Ecological traits predicting amphibian population declines in Central America. Conserv Biol 17:1078-1088

Lips KR, Brem F, Brenes R, Reeve JD and others (2006) Emerging infectious disease and the loss of biodiversity in a Neotropical amphibian community. Proc Natl Acad Sci USA 103:3165-3170

Nichols DK, Laraminde E (2001) Successful treatment of chytridiomycosis. Froglog 46. Available at: www.open.ac. uk/daptf/froglog/FROGLOG-46-1.html

Piotrowski JS, Annis SL, Longcore JF (2004) Physiology of Batrachochytrium dendrobatidis, a chytrid pathogen of amphibians. Mycologia 96:9-15

$>$ Pough F, Taigen T, Stewart M, Brussard P (1983) Behavioral modification of evaporative water loss by a Puerto Rican frog. Ecology 64:244-252

> Pounds J, Crump M (1994) Amphibian declines and climate disturbance: the case of the golden toad and the harlequin frog. Conserv Biol 8:72-85

Pounds JA, Bustamante MR, Coloma LA, Consuegra JA and others (2006) Widespread amphibian extinctions from epidemic disease driven by global warming. Nature 439: 161-167

Retallick RWR, McCallum H, Speare R (2004) Endemic infection of the amphibian chytrid fungus in a frog community post-decline. PLoS Biol 2:e351

Rohr JR, Raffel TR, Romansic JM, McCallum H, Hudson PJ (2008) Evaluating the links between climate, disease spread, and amphibian declines. Proc Natl Acad Sci USA 105:17436-17441

Skerratt LF, Berger L, Speare R, Cashins S and others (2007) Spread of chytridiomycosis has caused the rapid global decline and extinction of frogs. EcoHealth 4:125-134

Stewart M (1995) Climate driven population fluctuations in rain forest frogs. J Herpetol 28:369-378

Twitty V (1966) Of scientists and salamanders. Freeman, San Francisco, CA

Submitted: November 11, 2008; Accepted: March 2, 2009

Proofs received from author(s): April 21, 2009 